\title{
Ebola Disease and Health Care Workers Heroism
}

\section{Edmond Puca*}

Service of Infection Diseases University Hospital Center "Mother Teresa", Tirana, Albania

"Corresponding author: Edmond Puca, Service of Infection Diseases University Hospital Center "Mother Teresa”, Tirana, Albania, Tel: 0672058624; E-mail: edmond_puca@yahoo.com

Received date: November 24, 2014, Accepted date: November 25, 2014, Published date: November 28, 2014

Copyright: (C) 2014 Edmond Puca. This is an open-access article distributed under the terms of the Creative Commons Attribution License, which permits unrestricted use, distribution, and reproduction in any medium, provided the original author and source are credited.

\section{Editorial}

Hemorrhagic fevers are a group of illnesses, which are characterized by fever and associated with bleeding. Hemorrhagic fevers are caused by several viruses. These diseases are found around the world, mostly in America, Asia and Africa, but also in Europe they are problematic.

\begin{tabular}{|l|l|l|}
\hline FAMILY & VIRUS RESPONSIBLE & DISEASE \\
\hline Arenaviridae & $\begin{array}{l}\text { Lassa virus } \\
\text { Junin virus } \\
\text { Machupo virus }\end{array}$ & $\begin{array}{l}\text { Lassa fever } \\
\text { Argentine hemorrhagic fever } \\
\text { Bolivian hemorrhagic fever }\end{array}$ \\
\hline Bunyaviridae & $\begin{array}{l}\text { Crimean-Congo hemorrhagic } \\
\text { fever virus } \\
\text { Rift Valley Fever virus } \\
\text { Hantaan hemorrhagic fevers } \\
\text { viruses }\end{array}$ & $\begin{array}{l}\text { Crimean-Congo hemorrhagic } \\
\text { fever } \\
\text { Rift Valley Fever } \\
\text { Hemorrhagic fevers } \\
\text { renal sindrome } \\
\text { HPS }\end{array}$ \\
\hline Filoviridae & $\begin{array}{l}\text { Ebola virus } \\
\text { Marburg virus }\end{array}$ & $\begin{array}{l}\text { Ebola disease } \\
\text { Marburg disease }\end{array}$ \\
\hline Flaviviridae & $\begin{array}{l}\text { Yellow fever virus } \\
\text { Omsk hemorrhagic fever virus } \\
\text { Kyasanur forest disease virus }\end{array}$ & $\begin{array}{l}\text { Omsk hemorrhagic fever } \\
\text { Kyasanur forest disease } \\
\text { Dengue disease }\end{array}$ \\
\hline
\end{tabular}

Table 1: Viral Families Causing Viral Hemorrhagic Fever
The hemorrhagic fever generally has had local character, but changes in climatic conditions have affected the localizations and outbreaks. Due to their aggressive character, all the time, these diseases have been a challenge for health care system. It is certain that every disease have their way of spread, but nowadays people movements from a country to another and the development of tourism has make their prevalence impossible to control or manage. This article is not focus on epidemiology, etiology, transmission and clinical aspect of the Ebola disease, but in the heroism of health care workers. For instance, these epidemic infections are found even in the health care workers. These cases can be only explained by evidencing the difficulties in securing protective medical equipment (PPE), getting the right information about the disease etc. In particularly referring to Ebola, this is known since her first outbreak in 1976 in Zaire [1-4]. This outbreak was the first recognition of the disease. Since then, there have been chronological outbreaks of Ebola virus disease. Last Ebola outbreaks have started in the beginning of this year and the following countries: Liberia, Sierra Leone and Guinea constitute about $97 \%$ of all cases. The Ebola epidemic is the largest in history and it is affecting multiple countries in West Africa and so on some acquired cases in healthcare workers in the US. The mortality rate of this epidemic disease is increasing at very threatening levels. Since December 2013, and as of 12 October 2014, 8997 cases of EVD, including 4493 deaths, have been reported by the World Health Organization (WHO) in seven reporting countries (Guinea, Liberia, Nigeria, Senegal, Sierra Leone, Spain and the USA) [2]. On the other hand according to the last surveys of WHO this is the first world epidemic that has reached a record figure at a very high range by infecting the healthcare workers [3].

\begin{tabular}{|l|l|l|}
\hline Country & Cases & Deaths \\
\hline Guinea & 88 & 46 \\
\hline Liberia & 315 & 157 \\
\hline Nigeria & 11 & 5 \\
\hline Sierra Leone & 128 & 102 \\
\hline Spain & 1 & 0 \\
\hline United States of America & 3 & 0 \\
\hline Total & 546 & 310 \\
\hline
\end{tabular}

Table 2: Ebola virus disease infections in health-care workers

It obvious to have questions like: -How is it possible to have so many infected cases of healthcare workers, when Ebola it is not transmitted through the air, like the flu virus. Because the natural reservoir host of Ebola viruses has not yet been identified the way in which the virus first appears in human. The direct contact with Ebola patients, also by not wearing appropriate personal protective equipment (PPE) healthcare workers are at the highest risk of getting infected. What is more important is the heroic behavior of the 
Page 2 of 2

healthcare workers, who are showing their humanity by disregarding their lives. The high rate mortality is an example for that. This epidemic disease has proved another time the commitment and devotion of all the healthcare workers (nurses, doctors, sanitary) by supporting the idea that "Everyone has the right to standard of living adequate for the health and the well-being". So here comes another question- How long will this massacre continue? Till when the health care system will be in a position to afford a situation like that, and will they be able to prevent death anymore? For that reason the whole health system should find promising treatments and strength mechanisms in regard of all the lost lives. They are the modern heroes of health.

\section{Conclusion}

The recent outbreaks of Ebola have shown that infective diseases have been, are and will always be a "time bomb" for the health system. Aside from the human cost, the outbreak has severely eroded the economies of the affected countries, so it is now a political case to. In the end the world should not forget the past of the infective diseases. Clearly the first priority for early recognition of potentially dangerous outbreaks must be to educate the health and administrative authorities, particularly in the tropics, of the need for some form of surveillance and reporting of outbreaks of acute febrile disease. For this time Ebola showed that it is not just a national concern but a worldwide problem. So let it serve as a lesson for the next few years in organizing, evaluating of every disease in the health care system. Special regards to all the lost lives who fought for this epidemic situation and for the future!

\section{References}

1. World Health Organization. Ebola hemorrhagic fever in Zaire, 1976. Report of an International Convention (1978) Bulletin of the World Health Organization. 56 (2): 271-293.

2. European Centre for Disease Prevention and Control. Outbreak of Ebola virus disease in West Africa. (2014) Seventh update, 17 October 2014. Stockholm: ECDC.

3. System Ebola Epidemiology Team IM (2014) Update: ebola virus disease epidemic - west Africa, november 2014. MMWR Morb Mortal Wkly Rep 63: 1064-1066.

4. Canadian Critical Care Society. Ebola Clinical Care Guidelines (2014) Interim Report August 29, 2014 